\title{
KONUT SATIN ALIMINDA ALTERNATİF BİR KARAR DESTEK SİSTEMİ ÖNERİSI
}

\author{
Emrah AYDEMİR ${ }^{1 *}$, Cemal AKTÜRK², Mehmet Ali YALÇINKAYA ${ }^{1}$
}

${ }^{1}$ Kırşehir Ahi Evran Üniversitesi, Bilgisayar Mühendisliği Bölümü, Kırşehir, Türkiye

${ }^{2}$ Gaziantep İslam Bilim ve Teknoloji Üniversitesi, Bilgisayar Mühendisliği Bölümü, Gaziantep, Türkiye

\begin{abstract}
Anahtar Kelimeler
Konut Satın Alma,

Karar Destek Sistemi, Model.
\end{abstract}

\begin{abstract}
Öz
Barınma ihtiyacı, eski çağlardan günümüze kadar insanların en temel ihtiyaçları arasındaki yer almıştır. İnsanların barınma ihtiyacını karşılamak için kullanılan evler, yaşanan coğrafya, kullanılan malzeme vb. açısından çeşitli farklılıklar göstermektedir. Bu farklılıklar, yapısal, güvenlik, ısınma, donanım ve yakınlık olarak beş ayrı kategori altında toplanabilir. Her bir kategori ise kendi alt gruplarına sahiptir. Mevcut konut satın alma sistemleri, konut özelliklerinin varlık ya da yokluk durumunu dikkate alarak ilanları sıralamaktadır. Fakat her alıcı için özellikleri sadece lojik 0 ya da lojik 1 ile ifade etmek uygun değildir. Bu gibi sorunları çözmek için alıcıların her bir kategoriye ve altındaki özelliklere -1 ile +1 arasında bir değer vermesinden oluşan bir model ortaya çıkarılmıştır. Bu sorunu çözmek için alıcıların kategoriler ve alt kategorilere -1 ile +1 arasında bir değer verilmesine dayanan bir model olușturulmuş ve sunulmuștur. Bu model kullanılarak olușturulan listede her konutun bir puanı oluşmakta ve alıcıya sıralanarak gösterilmektedir. Böylece alıcı için karar almada mevcut sistemlere kiyasla daha gerçekçi bir liste oluşturulmaktadır. Bu çalışmada İstanbul ilinin 39 ilçesindeki toplam 34844 konut incelenmiş ve 29 kriterden oluşturulan model geliștirilmiștir. Geliştirilen model, 40 adet örnek için test edilerek karar destek sisteminin yeterliliği gösterilmiştir. Ayrıca kişiye özel olarak sunulan alternatif bir karar destek sistemi ile sıralama tablosu gösterilmiștir.
\end{abstract}

\section{AN ALTERNATIVE DECISION SUPPORT SYSTEM PROPOSAL IN HOUSE PURCHASE}

\begin{tabular}{l}
\hline Keywords \\
\hline Buying House, \\
Decision Support System, \\
Model.
\end{tabular}

\begin{abstract}
The need for shelter has been among the most basic needs of people since ancient times. Houses used to meet people's accommodation needs differ in terms of geography, materials used and etc. These differences can be categorized under five categories: structural, security, heating, hardware and proximity. Each category has its own subgroups. Existing home purchasing systems list the postings taking into account the presence or absence of residential properties. However, it is not appropriate for buyers to mean the properties only with logic 0 or logic 1 values. To solve such problems, a model is created where buyers give a value between -1 and +1 to each category and the attributes under it. In the list created using this model, each house has a score and is shown to the buyer in order. Thus, a more realistic list is created that will assist the buyer in making decisions, compared to existing systems. In this study, a total of 34844 houses in 39 districts of Istanbul province were examined and a model formed from 29 criteria was developed. The developed model was tested for 40 samples and the adequacy of the decision support system was demonstrated. In addition, an alternative decision support system offered exclusively to the person and the ranking table is shown.
\end{abstract}

Alıntı / Cite

Aydemir, E., Aktürk, C., Yalçınkaya, M.A., (2020). Konut Satın Alımında Yeni Bir Karar Destek Sistemi Önerisi, Mühendislik Bilimleri ve Tasarım Dergisi, 8(3), 677-691.

\footnotetext{
* ilgili yazar / Corresponding author: emrah.aydemir@ahievran.edu.tr, +90-386-280-38-00
} 


\begin{tabular}{l|l|l}
\hline Yazar Kimliği / Author ID (ORCID Number) & Makale Süreci / Article Process \\
\hline E. Aydemir, 0000-0002-8380-7891 & Başvuru Tarihi / Submission Date & 17.02 .2020 \\
C. Aktürk, 0000-0003-3764-3862 & Revizyon Tarihi / Revision Date & 23.06 .2020 \\
M.A. Yalçınkaya, 0000-0002-7320-5643 & Kabul Tarihi / Accepted Date & 28.06 .2020 \\
& Yayım Tarihi / Published Date & 24.09 .2020 \\
\hline
\end{tabular}

\section{Giriş (Introduction)}

İnsanların yaşamlarını sürdürebilmeleri için gidermeleri gereken en temel ihtiyaçlarının başında beslenme, giyim ve barınma gelmektedir. Barınma ihtiyacının temelinde, insanların kendilerini fırtına, kasırga, soğuk hava, heyelanlar ve zararlı canlılardan korumak yatmaktadır. İnsanlar; en ilkel çağlardan günümüze kadar, barınma ihtiyaçlarını bir șekilde karşılayabilmek için sürekli arayış içinde olmuşlardır. İnsanların barınma ihtiyacını karşılayan ev kavramı, göçebe toplumlardan yerleşik hayata geçen toplumlara kadarki tüm zaman dilimlerinde, farklı yapı ve formlarda ortaya çıkmıştır. Evler, bulunduğu coğrafyanın iklimine, yapısında kullanılan teknoloji ve malzemeye göre tarih boyunca değişiklik göstermiş ama insan hayatının vazgeçilmez unsuru olmaya devam etmiştir (Altun, 2017).

Konut sahibi olarak barınma ihtiyacının karşılanması, Maslow’un ihtiyaçlar hiyerarşisinde önemli bir yere sahiptir. Çünkü Maslow'un ihtiyaçlar hiyerarşisine göre nefes alma, yemek yeme, su içme gibi fizyolojik ihtiyaçlarını karşılayabilen bir insanın, yaşamının devamını sağlayabilmesi için, güvenlik ihtiyaçlarından olan barınma gereksinimini de karşılaması gerekmektedir. Barınma gereksinimini karşılayan bir insan, kendini gerçekleştirme doğrultusunda, diğer ihtiyaçları için çalışabilecektir (Baran, 2007).

Günümüzde insanların barınma ihtiyacını karşılayacak evlerin satın alınabilmesi için yüksek oranda maddi kaynak yaratılması gerekmektedir. Her ne kadar kiralama yöntemi ile barınma ihtiyacının karşılanması mümkün olsa da, insanlar için genel amaç kendisine ait bir eve sahip olmaktır. Evler, insanların barınma ihtiyacını karşılamanın yanı sıra sosyal statülerini de simgeler duruma gelmiştir. Ev alma davranışı, insanlar için temel barınma ihtiyacını karşılamasının yanında, bazı durumlarda da yatırım amacı ile gerçekleştirilmektedir. Evler, değișen piyasa koşulları ve enflasyon oranları karşısında insanların birikiminin erimesine engel olan bir yatırım aracı olarak görülmektedir. Yatırım amacı ile alınan evlerin kiraya verilmesi, kişiler için ek bir gelir kaynağı da oluşturmaktadır.

Ev sahibi olmak için yeterli seviyede kaynağa sahip olan insanlar, sahip oldukları parayı kendilerince alınabilecek en mantıklı ev için kullanmayı amaçlamaktadırlar. Çünkü konut satın alımı; geri dönüşü olmayan, tek seferde en uygun seçeneğin tespit edilmesi gereken bir işlem olarak görülmektedir. Bu işlem, günümüz maddi koşullarında birçok aile için, bir kez yapılabilecek bir yatırım olma özelliği taşımaktadır. İnsanlar için bu denli önem arz eden ev alımında dikkat edilmesi gereken çeşitli kriterler bulunmaktadır. Konut alımında tüketicilerin dikkat etmesi gereken kriterler, Gayrimenkul ve Gayrimenkul Yatırım Ortaklığı Derneği tarafından bir listede yayınlanmıştır (GYODER, 2013). Aşağıda söz konusu kriterlerden başlıcaları verilmiştir.

- Satın almayı düşündüğünüz konutun kent merkezine göre konumu nedir? Toplu tașıma, hastane, okul, alışveriş merkezi gibi sosyal ihtiyaçlara olan yakınlığını araştırdınız mı?

- Konutunuzun gördügü cephe nedir ve en yakın bina ile arasındaki mesafe kaç metredir?

- Satın almayı düşündügünüz konutun brüt ve net alanlarını biliyor musunuz? Kat planlarını incelediniz mi?

- Satın almayı düşündügünüz konutun satış fiyatına nelerin dahil olduğunu araştırdınız mı?

- Satın almayı düşündüğünüz konutun bulunduğu projede otopark, sosyal tesis ve spor alanları olup olmadığını, varsa bu alanların kullanımının bir ücrete tabi olup olmadığını öğrendiniz mi?

- Satın almayı düşündüğünüz konutun bulunduğu binanın ısıtma sistemi, ısı ve ses yalıtımı konusundaki taşıdı̆̆ı özellikleri biliyor musunuz?

- Satın almayı düşündüğünüz konutun ortak giderlere katılım payı/aidatı sizin için kabul edilebilir düzeyde mi?

Yukarıda listelenen kriterler, yayınlanan liste içerisindeki diğer kriterlerin sadece küçük bir kısmını oluşturmaktadır. Konut alımında dikkat edilmesi gereken kriter sayısının fazlalığı, alınacak kararın önemi ile birleştiğinde, insanların doğru seçimi yapmasında yardımcı olacak sistemlerin önemi büyük önem kazanmaktadır. Karar destek sistemleri (KDS), çeşitli problemler karşısında insanların daha verimli kararlar almalarına yardımcı olmak için geliştirilen bilgisayar destekli sistemlerdir. Söz konusu sistemler, karar verici kişilerin çeşitli kriterler ve kanıtlara dayalı olarak karar vermelerine yardımcı olmaktadır. Günümüzde karşılaşılan problemlerdeki seçeneklerin sayısının fazla olmasının yanında, kararı etkileyen kriterler arasındaki ilişkinin karmaşıklığı, insanların karar destek sistemlerine olan ihtiyacının artmasına neden olmuştur. Karar destek sistemleri, karar vermekle yükümlü kişilere yardımcı olabilmek adına çeşitli analitik modeller, veri tabanları ve etkileşimli kullanıcı ara yüzü içermektedir (Çil vd., 2014). Çeşitli problemler karşısında, karar vericilere destek olmak amacı ile 
kullanılan 5 farklı türde karar destek sistemi bulunmaktadır. Bunlar; iletişim odaklı KDS, veri odaklı KDS, belgeye dayalı KDS, bilgi temelli KDS ve model odaklı KDS'dir. Veri odaklı KDS’leri; mevcut problemi çözmek adına uzmanlar tarafindan oluşturulmuş büyük veri setlerini işleyerek, karar vericilere destek sunan sistemlerdir (Power, 2002).

Çalışmanın ikinci bölümünde kullanılan yöntem, üçüncü bölümünde ise elde edilen araştırma bulguları verilmiştir. Çalışma, elde edilen bulguların tartışılması ve sonuçların sunulması ile tamamlanmıştır.

\section{Kaynak Araştırması (Literature Survey)}

Literatürde insanların konut alımındaki kriterleri üzerine çeşitli çalışmalar bulunmaktadır. Tosun ve Fırat (2012) çalışmalarında; Bursa ilinde yaşayan insanların konut seçerken dikkate aldıkları kriterlerin belirlenmesi için bir anket çalışması gerçekleştirmişlerdir. Yayar ve Deniz (2014) çalışmalarında Mersin, Daşkıran (2015) çalışmasında Denizli kentlerinde konut taleplerine etki eden kriterlerin belirlenmesinde hedenik modeli kullanmışlardır. Aktürk ve Tekman (2016) gerçekleştirilen çalışmalarında, Erzurum kent merkezinde ikamet eden 640 kullanıcının, konut alımında dikkat ettiği kriterler betimsel tarama modeli ile tespit edilmeye çalışılmıştır. Ayrıca Şenyurt (2001), Baran (2007), Güneş (2009), Coşkun (2012) ve Şengül (2018) ülkemizde aile ve şahısların konut alma süreçlerinde dikkat ettikleri kriterler üzerinde çalışmalar gerçekleştirmişlerdir. Literatürde karar destek sistemleri alanında gerçekleştirilen çalışmalardan incelenen ilk çalışma; Kul (2010) tarafından gerçekleștirilmiştir. İlgili çalışmada, büyükşehirler çevresinde yapılandırılan uydu kentlerin tasarlanmasında kullanılacak bir KDS geliştirilmiştir. Yavuz ve Çemrek (2013) çalışmalarında, sağlık çalışanlarının konut tercihlerini belirlemek amacı ile konjoint analiz tekniği kullanılmıştır. Nuuter ve Lill (2014) çalıșmalarında, geliştirmiş oldukları bir KDS ile, Estonya' da konut piyasasının sürdürülebilirliğini analiz etmişlerdir. Hamurcu ve Eren (2015) çalışmalarında, yerel yönetimlerde ulaşım problemini çözmede kullanılan toplu taşıma sistemlerinin en büyük problemi olan güzergâh belirleme işlemi için bir KDS geliștirmişlerdir. Alaybeyoğlu vd. (2016) çalışmalarında; herhangi bir şehirde aynı anda birden fazla mahallede kentsel dönüşüme ihtiyaç duyulması durumunda, aciliyet durumuna göre ișleme hangi mahalleden bașlanılacağını belirleyen bir KDS geliștirmişlerdir. KDS’ler lojistik sektöründeki problemlere çözüm üretiminde (Kamışlı Öztürk, Güngör ve Lepki, 2016) kullanılmasının yanı sıra tedarikçi seçimi (Şahin ve Supçiller, 2015) gibi farlı karar verme durumlarında da kullanılmaktadır. KDS'leri daha hayati olan konulardan acil servislerde kullanımını görmek mümkündür (Özkaraca vd., 2018). Bostancı vd. (2017) gerçekleştirdikleri çalışmalarında bulanık karar verme tekniklerini kullanarak, iki farklı TOKI toplu konut bölgesinde ikamet eden insanların, konutları hakkında memnuniyetlerini etkileyen faktörleri değerlendirmişlerdir.

Literatürde incelenen çalışmalar ile karşılaştırıldığında bu çalışma, oluşturulan veri seti ve problemin çözümü için geliştirilen karar destek sistemi yapısı yönünden özgün olma özelliği taşımaktadır.

\section{Materyal ve Yöntem (Material and Method)}

$\mathrm{Bu}$ çalışmada; konut alım sürecinde kendisine verilen talepler doğrultusunda müşteriye uygun evlerin filtrelenmesinde kullanılacak, veri odaklı bir karar destek sistemi geliştirilmiştir. Konut alma karar destek modeli için öncelikle Türkiye'deki en fazla hane ve en fazla konut sayısına sahip olan İstanbul ili için geniş kapsamlı bir veri toplama çalışması yapılmıştır. Bunun için internet üzerindeki emlak ilan siteleri taranarak satılık daire ilanlarının tüm ayrıntıları her ilçe için ayrı kaydedilerek daha sonra tüm ilçeler birleştirilmiştir. Son durumda İstanbul'a ait 39 ilçenin tamamı için satılık daire ilan verileri elde edilmiştir. Araştırma verilerinin sağlıklı bir şekilde analiz edilebilmesi için her ilçe için 1000'e yakın güncel ilanlar araştırılmıştır. Bazı ilçelerin toplam ilan sayısı 1000'e ulaşmadığından dolayı bu ilçeler için var olan tüm ilanlar kaydedilmiştir. Daha sonra belirlenen her bir satılık ilanından, 29 farklı öznitelik verisi çıkartılarak bir veri seti oluşturulmuştur. Toplanan verilerden oluşturulan veri seti içerisinde 34844 örnek bulunmaktadır. Oluşturulan veri seti, alacakları konutun sahip olmasını istedikleri özellikler doğrultusunda, insanların en mantıklı kararı vermelerine yardımcı olacak bir karar destek sisteminin geliştirilmesinde kullanılmıștır. Oluşturulan karar destek sisteminin, farklı ilanlar arasından, kullanıcı talepleri doğrultusunda oluşturulan ağırlık katsayılarına göre, alınması en mantıklı ilanları başarı ile sıraladığg görülmüştür.

\subsection{Kriterlerin Belirlenmesi (Determination of Criteria)}

Konut alma karar sürecinde alternatifleri değerlendirmede kullanılacak kriterler için öncelikle literatürdeki çalışmalar incelenmiştir. Bu çalışmalarda konut alma problemi için kullanılan kriterler: konutun kullanım alanı (m2), oda sayısı, banyo sayısı gibi yapısal özelliklerden; garaj, asansör, havuz, otopark gibi olanaklardan ve sosyokültürel ihtiyaçların sunulduğu mekânlara olan uzaklıkları belirten kriterlerden oluşmaktadır (Aydın ve Erdoğan, 2011), (Tosun ve Fırat, 2012), (Özgür, 2013), (Yavuz ve Çemrek, 2013), (Yayar ve Deniz, 2014), (Aktürk ve 
Tekman, 2016). Yapılan çalışmalarda ortak olarak kullanılan kriterler belirlenmiştir. Bu kriterlere ilave olarak konut alma kararına etkisi olacak birtakım kriterler de ilave edilmiştir. Sonrasında belirlenen kriterleri konutun yapısal özellikleri, güvenlik ve ısı ihtiyaçlarının karşılanması, konutun donanımsal özellikleri ve çeşitli mekânlara yakınlık durumlarına göre sınıflandırarak beş ana kategoriden oluşan bir karar modeli tasarlanmıştır. Karar modelinde kullanılması planlanan kriterler hiyerarşik olarak şu şekilde gösterilir.

1.Yapisal

1.1.Alan (m2)

1.2.0da Sayısı

1.3.Bina Yaşı

1.4.Banyo Sayısı

1.5.Giyinme Odası

1.6.Kiler

2.Güvenlik

1.7.Araç Park Yeri

2.1.Hirsız Alarmı

2.2.Yangın Alarmı

2.3.Görüntülü Diyafon

2.4.Yüz tanıma / Parmak izi tanıma

2.5.Çelik Kapı

2.6.Güvenlik Personeli

2.7.Yangın Merdiveni

2.8.Polis Merkezi

3.Isınma

2.9.İtfaiye

3.1.Cephe Durumu

3.1.1.Doğu

3.1.2.Güney

3.1.3.Batı

3.1.4.Kuzey

3.2.Kat Durumu

3.2.1.Ara kat

3.2.2.Giriş kat

3.2.3.En üst kat

3.3.Isicam

3.4.Isı Yalıtımı

4.Donanım

4.1.Akıllı Ev

4.2.Alaturka Tuvalet

4.3.Sauna

4.4.Havuz

4.4.1.Müstakil Özel Havuz

4.4.2.Açık Havuz (Ortak Kullanım)

4.4.3.Kapalı Havuz (Ortak Kullanım)

5.Yakınlık

4.5.Asansör

5.1.Eğitim Hizmetleri

5.1.1.İlkokul - ortaokula yakınlık

5.1.2.Liseye yakınlık

5.1.3.Üniversiteye yakınlık

5.2.Sağlık Hizmetleri

5.2.1. Hastaneye yakınlık

5.2.2.Sağlık ocağı / tıp merkezi / kliniğe yakınlık

5.3.Sosyal İhtiyaçlar

5.3.1.Alışveriş merkezine yakınlık

5.3.2.Semt pazarına yakınlık

5.3.3.Markete yakınlık

5.3.4.Parka yakınlık

5.4.Ulaşım

5.4.1.Şehir merkezine yakınlık

5.4.2.Anayola yakınlık 
5.4.3.Dolmuş durağına yakınlık

5.4.4.Otobüs durağına yakınlık

5.4.5.Metro istasyonuna yakınlık

5.4.6.Marmaray istasyonuna yakınlık

5.4.7.Metrobüs durağına yakınlık

5.4.8.Tramvay durağına yakınlık

Yakınlık kriterleri, satılık daire ilanlarında ilan verenin, dairesinin bu mekanlara yakın olup olmadığı konusundaki beyanatına göre hesaplanmış olup bu hesaplamada herhangi bir mesafe büyüklügü kullanılmamaktadır. İlgili mekanlara yakın olanlar için "1", yakınlık durumu belirtilmeyenler için "0" ataması yapılarak kriter hesaplamaları yapılmıștır. Yine benzer șekilde sayısal bir büyüklük belirtmeyen güvenlik, ısınma ve donanım kriterlerinin tamamı ile yapısal kriterlerden "kiler", "araç park yeri" kriterleri için sadece "var/yok" verisi belirtildiğinden kriter değeri "var" olanlar "1" değeri ile, "yok" olanlar ve belirtilmemiş olanlar ise "0" değeri ile analiz edilmiştir.

\subsection{Doğrusal Karar Modelinin Matematiksel İfadesi (Mathematical Expression Of The Linear Decision Model)}

Buradaki çalıșmada ağırlıklı toplam modelinin (Wikipedia, 2019) uygulanmasıyla alternatif bir karar destek sistemi önerilmiştir. Her bir alternatif ve kriteri öncelikle bir matrise dönüştürmek gerekmektedir. Bu amaçla a1,a2,...an alternatifleri ifade etmek için kullanılacak olursa; karar modelinde kullanılan her bir kriter, 1. alternatif için a11,a12,a113...a1m şeklinde ifade edilirse alternatif ve kriterlerden oluşan ve henüz işlem görmemiş $\mathrm{n} \times \mathrm{m}$ boyutundaki K matrisi Denklem 1'de gösterildiği gibi olușturulur.

$$
K=\left[\begin{array}{ccccc}
a 11 & a 12 & a 13 & . . & a 1 m \\
a 21 & a 22 & a 23 & . . & a 2 m \\
a 31 & a 32 & a 33 & . . & a 3 m \\
a i j & . & . . & . . & . . \\
a n 1 & \text { an2 } & \text { an3 } & . . & \text { anm }
\end{array}\right]
$$

2. aşamada, her bir kriteri ifade eden $\mathrm{K}$ matrisinin sütunları için maksimum değerler (max aij) hesaplanır ve her bir aij, hesaplanan maksimum kriter değerine bölünerek Denklem 2'deki gibi normalize edilmiş K matrisi elde edilir.

$$
n K=\left[\begin{array}{ccc}
a 11 / a 1 \max & \text { a12/a2max } & \text { a13/a3max } \\
\text { a21/a1 max } & a 22 / a 2 \max & \text { a23/a3max } \\
a 31 / a 1 \max & a 32 / a 2 \max & \text { a33/a3max } \\
\text { aij/a1max } & . . & . . \\
\text { an1/a1max } & \text { an2/a2max } & \text { an } 3 / a 3 \max
\end{array}\right]
$$

Sonrasında nK matrisinin her elemanının çarpma işlemine göre tersi alınarak doğrusal K matrisi elde edilir. Matris elemanları doğrusallaştırıldıktan sonra her bir sütundaki maksimum değerler yeniden hesaplanarak doğrusal matris yeniden normalize ișlemine tabi tutularak karar matrisi elde edilir. Son durumda her bir alternatif için f1,f2,..fn ile ifade edilen amaç fonksiyonu Denklem 3'te gösterildiği gibi karar matrisi elemanlarını (xij) ağırlık katsayılarına çarpılarak ağırlıklı toplamlarıyla hesaplanır. Ağırlık katsayılarının toplamı Denklem 4'te gösterildiği gibi 1'e eşit olmak zorundadır. Son durumda alternatifler amaç fonksiyonu değerlerine göre büyükten küçüğe doğru sıralanarak en iyi değere sahip alternatif, ilgili karar probleminin çözümünü verir.

$$
\begin{gathered}
{\left[\begin{array}{c}
f 1 \\
f 2 \\
f 3 \\
\vdots \\
f n
\end{array}\right]=\left[\begin{array}{ccccc}
x 11 & x 12 & x 13 & . . & x 1 m \\
x 21 & x 22 & x 23 & . . & x 2 m \\
x 31 & x 32 & x 33 & . . & x 3 m \\
x i j & . . & . . & . . & . . \\
x n 1 & x n 2 & x n 3 & . . & x n m
\end{array}\right] X\left[\begin{array}{c}
W 1 \\
W 2 \\
W 3 \\
\vdots \\
W m
\end{array}\right]} \\
\sum_{i=1}^{n} W i=1
\end{gathered}
$$

\subsection{Konut Alma Karar Modeli (Housing Decision Model)}

Beş ana kategoride sınıflandırılan kriterler geliştirilen doğrusal karar modelinde de aynı şekilde fonksiyonlara dönüştürülerek bu fonksiyonların ağırlıklı toplamı olarak amaç fonksiyonunda Denklem 5'teki gibi ifade edilmiştir. F fonksiyonunun maksimum edilmesi amaçlanmıştır. Bir başka ifade ile konut alternatifleri için 
hesaplanan F fonksiyonu değerlerine göre büyükten küçüğe doğru sıralanması, ilgili karar probleminin çözümünü oluşturacak ve en büyük F değerine sahip alternatif, belirtilen önceliklere göre alınabilecek en iyi konut olacaktır.

$$
\mathrm{F}(\mathrm{X})=W_{1} B(\mathrm{X})+W_{2} S(\mathrm{X})+W_{3} T(\mathrm{X})+W_{4} H(\mathrm{X})+W_{5} I(\mathrm{X})
$$

Denklem 5'te; W_1, W_2,... W_5'ler ana kriterlerin amaç fonksiyonu içerisindeki ağırlık katsayılarını ifade etmektedir ve toplamları Denklem 4'te gösterildiği gibi 1'e eșit olmalıdır. B fonksiyonu yapısal kriterleri, S fonksiyonu güvenlik kriterlerini, $\mathrm{T}$ fonksiyonu ısınma kriterlerini, $\mathrm{H}$ fonksiyonu donanım kriterlerini ve I fonksiyonu ise yakınlık kriterlerini ifade etmek için geliştirilen ana kriter fonksiyonlarıdır.

Yapısal kriterler fonksiyonunun gösterildiği Denklem 6'da, W_11, W_12,... W_18'ler kriterlerin ağırlık katsayılarını, m; dairenin metrekare cinsinden büyüklüğünü, r; oda sayısını, a; binanın yaşını, b; banyo sayısını, c; balkon sayısını, d; giyinme odasını, e; kileri, p fonksiyonu ise araç park yeri fonksiyonunu ifade etmektedir. Araç park yeri fonksiyonunun açılımı Denklem 7'de gösterilmiştir. Denklem 7'deki p (park) fonksiyonunda u; kapalı garajı, g; otoparkı, v ise araca ayrılmış park yerini belirtmektedir. Yine diğer denklemlerde olduğu gibi W ile gösterilen katsayılar her kriterin ağırlık katsayılarını ifade eder.

$$
\begin{gathered}
B(\mathrm{X})=W 1_{1} m+W 1_{2} r+W 1_{3} a+W 1_{4} b+W 1_{5} c+W 1_{6} d+W 1_{7} e+W 1_{8} p(x) \\
p(X)=W 18_{1} u+W 18_{2} g+W 18_{3} v
\end{gathered}
$$

Denklem 8'de gösterilen S fonksiyonu ise güvenlik ile ilgili kriterleri için kullanılmaktadır. Bu denklemde de W'ler kriter ağırlık katsayılarını, A; hırsızlık alarmını, f; yangın alarmını, V; görüntülü diyafonu, R; yüz/parmak izi tanıma sistemini, D; çelik kapıyı, H; güvenlik personelini, L; yangın merdivenini, P; polis merkezini, F ise itfaiyeyi belirtmektedir.

$$
S(X)=W 2_{1} A+W 2_{2} f+W 2_{3} V+W 2_{4} R+W 2_{5} D+W 2_{6} H+W 2_{7} L+W 2_{8} P+W 2_{9} F
$$

Isınma ile ilgili alt kriterler Denklem 9'da gösterilmiştir. Denklem 9'da; W'ler alt kriterlerin ağırlık katsayılarını, h fonksiyonu; dairenin cephe durumunu, fl fonksiyonu dairenin kat durumunu, d_g; Isıcam kriterini, t_i ise ısı yalıtımı kriterini belirtmek için kullanılmıştır. Cephe durumunun ayrıntıları Denklem 10'da gösterilmiştir. Cephe durumu; gün ışığı alan doğu, güney ve batı cepheleri ile güneş almayan kuzey cephesi için karar vericilerin tercihine göre belirlenecek ağırlık katsayılarıyla hesaplanmaktadır. East; doğu cephesini, West; batı cephesini, South; güney cephesini, North ise kuzey cephesini belirtmektedir. Isı yönünden avantajlı olması beklenen bir daire isteniyorsa, ilgili dairenin doğu, güney ve batıya cephelerinin olması tercih edilmeli, kuzey cephesi tercih edilmemelidir. Cephe tercihi için ağırlık katsayısı olarak -1 ile +1 arasındaki değerler kullanılabilir. Kat durumu fonksiyonu Denklem 11 'de gösterilmiştir. Bu denklemde ağırlık katsayısı kullanılmamıștır. Çünkü dairenin ara kat, en üst kat veya giriş kat dairesi olup olmadığı ilan verilerinden tespit edilebildiği için bu kriterlerden hangisi geçerli ise karşılığında değer olarak "1" ile Denklem 7 hesaplanır. Bir daire aynı anda hem ara kat hem en üst kat hem de giriş kat olamayacağı için diğer kriterler "0" olacağından daire ara kat ise fl fonksiyonu 1; en üst kat veya giriş kat ise -1 değerini alacaktır.

$$
\begin{aligned}
& T(X)=W 3_{1} \mathrm{~h}(\mathrm{x})+W 3_{2} \mathrm{fl}(\mathrm{x})+W 3_{3} d_{-} g+W 3_{4} t_{-} i \\
& h(X)=W 31_{1} \text { East }+W 31_{2} \text { West }+W 31_{3} \text { South }+W 31_{3} \text { North } \\
& \mathrm{fl}(\mathrm{x})=\text { floor }_{\mathrm{m}}-\left(f_{t}+f_{g}\right)
\end{aligned}
$$

Denklem 5'te gösterilen ve konuttaki donanımları ifade etmede kullanılan H fonksiyonunun ayrıntıları Denklem 12'de gösterilmiştir. Denklem 12'deki W'ler kriter ağırlık katsayılarını, s_h; akıllı ev kriterini, a_t; alaturka tuvalet kriterini, s_b; sauna kriterini, l; asansör kriterini, pl fonksiyonu ise havuz durumunu ifade etmek için kullanılmıştır. Havuz durumunu ifade eden pl fonksiyonunun ayrıntıları Denklem 13'te gösterilmektedir. Denklem 13'te W'ler ağırlık katsayılarını, [pr』_pool; daireye özel müstakil havuzu, o_pool; açık havuzu, i_poolise kapalı havuzu ifade etmektedir.

$$
\begin{aligned}
& H(X)=W 4_{1} s_{h}+W 4_{2} a_{-} t+W 4_{3} s_{-} b+W 4_{4} p l(X)+W 4_{5} l \\
& p l(X)=W 44_{1} p r_{p o o l}+W 44_{2} o_{p o o l}+W 44_{3} i_{\text {pool }}
\end{aligned}
$$


Denklem 14'teki I fonksiyonu yakınlık kriterlerini ifade etmek için kullanılmıştır. Denklem 14'teki W'ler kriter ağırlık katsayılarını, Sc fonksiyonu eğitim birimlerine olan yakınlı̆̆ı, Hl fonksiyonu sağlık birimlerine olan yakınlığı, Sh fonksiyonu sosyal ihtiyaç mekanlarına olan yakınlığı, Tr fonksiyonu ise ulaşım ile ilgili yerlere olan yakınlığı ifade etmektedir. Eğitim yerlerine olan yakınlığı ifade eden Sc fonksiyonunun ayrıntıları Denklem 15'te gösterilmiştir. Denklem 15'teki; W'ler kriter ağırlık katsayılarını, elschool; ilkokul ve ortaokulu, hischool; liseyi ve unischool da üniversiteyi ifade eder. Karar verici hangi eğitim kurumlarına daha yakın olan bir daire almak istiyorsa ilgili kriterin ağırlık katsayısını yüksek girip istemediğini düşük girerek böylelikle ilan verileri arasında kendi kriter ağırlıklarına göre ilanların önceliklendirilmesini sağlamış olur.

$$
\begin{aligned}
& I(X)=W 5_{1} S c(X)+W 5_{2} H l(X)+W 5_{3} S h(X)+W 5_{4} \operatorname{Tr}(X) \\
& S c(X)=W 51_{1} e l_{\text {school }}+W 51_{2} h i_{\text {school }}+W 51_{3} \text { uni } i_{\text {school }}
\end{aligned}
$$

Sağlık hizmetlerine yakınlığı belirten Hl fonksiyonunun ayrıntıları Denklem 16'da gösterilmiştir. W'ler yine kriter ağırlık katsayılarını, hospital; hastaneleri, clinic ise sağlık ocağı ve klinikleri ifade etmektedir.

$$
H l(X)=W 52_{1} \text { hospital }+W 52_{2} \text { clinic }
$$

Sosyal ihtiyaçlar için belirlenen ana kriter fonksiyonuna ait ayrıntılar Denklem 17'de gösterilmektedir. Burada; W'ler kriter ağırlık katsayılarını, mall; alışveriş merkezlerini, market; marketleri, park; parkları ve bazaar ise semt pazarlarını ifade etmek için kullanılmıștır.

$$
\operatorname{Sh}(X)=W 53_{1} \text { mall }+W 53_{2} \text { market }+W 53_{3} \text { park }+W 53_{4} \text { bazaar }
$$

Ulaşım yerlerine yakınlığı ifade etmede kullanılan Tr fonksiyonunun ayrıntıları Denklem 18'de gösterilmektedir. Denklem 18 incelenecek olursa; W'ler kriter ağırlık katsayılarını, central; şehir merkezine olan yakınlı̆̆ı, arterialroad; ana yola olan yakınlığı, minibus; dolmuş durağına yakınlığı, marmaray; Marmaray istasyonuna yakınlığı, metro; metro istasyonuna yakınlığı, metrobus; metrobüs istasyonlarına yakınlığı, tram ise tramvay durağına olan yakınlığı ifade etmede kullanılan kriter isimleridir.

$$
\begin{gathered}
\operatorname{Tr}(X)=W 54_{1} \text { central }+W 54_{2} \text { arterial }_{\text {road }}+W 54_{2} \text { minibus }+W 54_{2} \text { marmaray }+W 54_{2} \text { metro } \\
+W 54_{2} \text { metrobus }+W 54_{2} \text { bus }+W 54_{2} \text { tram }
\end{gathered}
$$

\subsection{Karar Modelinin Uygulanması (Implementation of the Decision Model)}

Öncelikle karar verici tarafından istenilen özelliklere göre filtrelenerek belirlenen konut ilan verileri bir elektronik veri kayıt sistemine kaydedilir. Yapılan çalışmada İstanbul ilinin Beylikdüzü ilçesindeki satılık daire ilanlarından rastgele 40 tanesi alınmıştır. Alternatif her ilan A1, A2 „,A40 olarak isimlendirilmiştir. Bir ilana ait karar modelinde kullanılan kriterler ise kendi adıyla girilmiștir. Tablo 1'de daire ilanlarına ait yapısal, güvenlik, ısıtma, donanım ve yakınlık kriterlerinin ekran görüntüsü görülmektedir. Ana kriterlere ve alt kriterlere ait kullanılan ağırlık katsayıları kriter isimlerinin üstündeki hücrelerde kırmızı renkli olarak gösterilmiştir. Tablo 1'de her bir ana kriterin fonksiyon değerinin ilgili bölümün son hücresinin yanında hesaplandığı gösterilmiştir. Tablo 1'nin en sağında ise her bir alternatif için hesaplanan amaç fonksiyonu (F) değerleri kırmızı renkle gösterilmiştir.

Karar modeli hesaplamalarında kriterlerden brüt m2, oda sayısı, bina yaşı ve banyo sayısı sayısal büyüklük olarak girilmiş olup diğer kriterler mevcutsa " 1 ", değilse " 0 " ile kaydedilmiştir. İlan verileri girildikten sonra öncelikle her bir kriter için en iyi olarak kabul edilen değerler belirlenir. Bina yaşı haricindeki tüm kriterlerin maksimum değerde olması, bina yaşının ise minimum değerde olması tercih sebebi olacağından bina yaşı kriteri için en iyi değer olarak diğer kriterlerden farklı șekilde minimum kriter değeri esas alınır. Bu sayede kriterler X_1, X_2,,, X_n şeklinde isimlendirilecek olursa; max Xi (bina yaşı için min X_i) değerleri hesaplanır. İkinci aşamada her bir alternatif için her bir kriter değeri ilgili kriter için hesaplanan en iyi değere bölünerek normalizasyon işlemi yapılmış olur. Örnek olarak yapısal kriterlere ait normalize edilmiş değerler tablosuna ait ekran görüntüsü Tablo 2'de gösterilmektedir. 


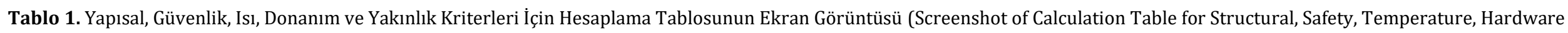
and Proximity Criterias)




Tablo 2. Yapısal Kriterlerin Normalize Değerler Tablosu (Table of Normalized Values of Structural Criteria)

\begin{tabular}{|c|c|c|c|c|c|c|c|c|c|c|c|}
\hline \multirow{4}{*}{ İan } & & & & & & & & YAP & w & & 30 \\
\hline & \multicolumn{11}{|c|}{ AĞIRUK KATSAYILARA } \\
\hline & 35 & 35 & 10 & 5 & 5 & 3 & 1 & 50 & 30 & 20 & \\
\hline & $\mathrm{m}^{2}$ (Brüt) & \begin{tabular}{c|} 
Oda \\
Says I \\
\end{tabular} & $\begin{array}{l}\text { Bina } \\
\text { Yaşı } \\
\end{array}$ & \begin{tabular}{|l|} 
Banyo \\
Say is
\end{tabular} & Balkon & KGler & \begin{tabular}{|c|} 
Giyinme \\
Odası
\end{tabular} & \begin{tabular}{|l} 
Araç Park \\
Yeri w=6 \\
Kapalı \\
\end{tabular} & $\begin{array}{l}\text { w } \\
\text { Otopark }\end{array}$ & Araç Park & 6 \\
\hline \multirow{2}{*}{ Ximax } & $\max$ & max & $\min$ & $\mathbf{m a x}$ & $\mathbf{m a x}$ & $\mathbf{m a x}$ & $\max$ & $\max$ & $\mathbf{m a x}$ & $\max$ & \\
\hline & 240 & 6 & 0,1 & 3 & 1 & 1 & 1 & 1 & 1 & & 1 \\
\hline \multicolumn{12}{|c|}{ Normalize Değerler } \\
\hline A1 & 0,33333333 & 0,5 & 0,033 & 0,3333 & 1 & 1 & 0 & 1 & 1 & & 1 \\
\hline A2 2 & 0,29166667 & 0,3333 & 0,033 & 0,3333 & 1 & 0 & 0 & 0 & 0 & & 0 \\
\hline $\mathbf{A 3}$ & 0,51666667 & 0,5 & 1 & 0,6667 & 1 & 0 & 1 & 0 & 0 & & 0 \\
\hline A4 & 0,47916667 & 0,6667 & 0,1 & 0,6667 & 1 & 0 & 0 & o & 0 & & 0 \\
\hline A5 & 0,5625 & 0,6667 & 1 & 0,6667 & 1 & 1 & 0 & 0 & 0 & & 1 \\
\hline A6 & 0,60416667 & 0,5 & 0,008 & 0,6667 & 1 & 0 & 1 & o & 1 & & 0 \\
\hline A7 & 1 & 0,8333 & 1 & 1 & 1 & 1 & 0 & 0 & 0 & & 0 \\
\hline $\mathbf{A 8}$ & 0,72916667 & 0,6667 & 0,008 & 0,6667 & 1 & 0 & 0 & 1 & 0 & & 0 \\
\hline A9 & 0,77083333 & 0,6667 & 0,007 & 0,6667 & 1 & 0 & 0 & 0 & 0 & & 0 \\
\hline A10 & 1 & 1 & 0,007 & 0,6667 & 1 & 0 & 0 & 0 & 0 & & 0 \\
\hline A11 & 0,13333333 & 0,1667 & 0,017 & 0,3333 & 0 & 1 & 1 & 0 & 0 & & 0 \\
\hline A12 & 0,24583333 & 0,3333 & 0,014 & 0,3333 & 1 & 0 & 0 & 1 & 0 & & 0 \\
\hline A13 & 0,27916667 & 0,3333 & 0,025 & 0,3333 & 0 & 0 & 0 & 0 & 0 & & 0 \\
\hline A14 & 0,3 & 0,3333 & 0,013 & 0,3333 & 1 & 0 & 0 & O & 0 & & 0 \\
\hline A15 & 0,32083333 & 0,3333 & 1 & 0,3333 & 1 & 0 & 1 & 0 & 1 & & 0 \\
\hline A16 & 0,29166667 & 0,3333 & 1 & 0,3333 & 0 & 1 & 0 & 0 & 0 & & 0 \\
\hline A17 & 0,27916667 & 0,3333 & 1 & 0,3333 & 1 & 0 & 0 & 0 & 0 & & 1 \\
\hline A18 & 0,35416667 & 0,5 & 0,033 & 0,3333 & 1 & 0 & 0 & 0 & 0 & & 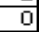 \\
\hline A19 & 0,33333333 & $\begin{array}{l}0,3333 \\
\end{array}$ & 0,011 & 0,3333 & 0 & 0 & 0 & 0 & 1 & & 0 \\
\hline A20 & 0,33333333 & 0,3333 & 0,01 & 0,3333 & 0 & 0 & 0 & 0 & 0 & & 0 \\
\hline A21 & 0,39583333 & 0,5 & 1 & 0,3333 & 1 & 1 & 0 & 1 & 0 & & 0 \\
\hline A22 & 0,39583333 & 0,5 & 1 & 0,3333 & 1 & 0 & 0 & 0 & 1 & & 0 \\
\hline A23 & 0,375 & 0,5 & 1 & 0,3333 & 1 & 0 & 0 & 0 & 0 & & 0 \\
\hline A24 & 0,45833333 & 0,5 & 1 & 0,3333 & 1 & 0 & 0 & 0 & 0 & & 1 \\
\hline A25 & 0,47916667 & 0,5 & 0,033 & 0,3333 & 1 & 1 & 0 & 0 & 1 & & 0 \\
\hline A26 & 0,45833333 & 0,5 & 1 & 0,3333 & 1 & 0 & 0 & 0 & 1 & & 0 \\
\hline A27 & 0,45833333 & 0,5 & 1 & 0,3333 & 1 & 1 & 0 & 0 & 1 & & 0 \\
\hline A28 & 0,41666667 & 0,5 & 1 & 0,3333 & 1 & 0 & 0 & 1 & 0 & & 0 \\
\hline A29 & 0,40833333 & 0,5 & 0,033 & 0,3333 & 1 & 1 & 0 & 0 & 0 & & 0 \\
\hline A30 & 0,45833333 & 0,5 & 1 & 0,6667 & 1 & 0 & 0 & 1 & 0 & & 0 \\
\hline A31 & 0,41666667 & 0,5 & 1 & 0,3333 & 1 & 0 & 0 & 1 & 0 & & 0 \\
\hline A32 & 0,39583333 & 0,5 & 0,02 & 0,3333 & 1 & 0 & 0 & 0 & 1 & & 0 \\
\hline A33 & 0,52916667 & 0,5 & 1 & 0,6667 & 1 & 0 & 0 & 0 & 0 & & 0 \\
\hline A34 & 0,5 & 0,5 & 1 & 0,3333 & 1 & 0 & 0 & 0 & 1 & & 1 \\
\hline A35 & 0,45833333 & 0,5 & 0,1 & 0,3333 & 1 & 1 & 0 & 0 & 0 & & 1 \\
\hline A36 & 0,5 & 0,5 & 1 & 0,3333 & 1 & 0 & 1 & 0 & 0 & & 1 \\
\hline A37 & 0,4875 & 0,5 & 1 & 0,3333 & 1 & 0 & 0 & 0 & 1 & & 0 \\
\hline A38 & 0,54166667 & 0,6667 & 0,033 & 0,3333 & 1 & 0 & 0 & 1 & 0 & & 0 \\
\hline A39 & 0,5 & 0,5 & 1 & 0,3333 & 1 & 0 & 0 & 0 & 1 & & 1 \\
\hline A40 & 0,49166667 & 0,5 & 0,1 & 0,6667 & 1 & 1 & 0 & 0 & 0 & & 0 \\
\hline
\end{tabular}

Bir sonraki aşamada normalize edilen kriter değerlerinin çarpma ișlemine göre tersi alınarak doğrusallaştırılması sağlanır. Burada 0'a bölme hatası olmaması için değerin 0'a eşit olup olmadığı da kontrol edilmektedir. Kriter değerleri için doğrusal karar matrisi oluşturulduktan sonra yeni tablo için tekrar en iyi değerler hesaplanır. Sonrasında her kriter için doğrusallaştırılan değerler maksimum değere bölünerek normalize edilmiş karar matrisi elde edilir. Karar matrisini hesapladıktan sonra yapılacak işlem ise artık Denklem 5'te gösterilen amaç fonksiyonunu ifade eden F fonksiyonunu hesaplamak için B, S, T, H ve I fonksiyonlarının değerlerini hesaplayarak bu fonksiyonların ağırlıklı toplamlarını almaktır. Fonksiyonların örnek 40 ilan için hesaplanan değerleri Tablo 1 ve Tablo 2'de fonksiyonların kendi adıyla belirtilen sütunlarda gösterilmektedir. Örnek hesaplamada kullanılan tüm ağırlık katsayıları toplamı 100'e eşit olacak şekilde örnek olarak girilmiş olup karar modelinde bu katsayılar 100'e bölünerek hesaplamalara dâhil edilmiştir.

\section{Araştırma Bulguları (Research Findings)}

\subsection{Satılık Daire İlanlarına Ait Bulgular (Findings About Apartments For Sale)}

Araştırmada İstanbul'un tüm ilçelerine ait toplam 34.843 adet satılık daire ilanı elde edilmiştir. Yapılan çalışmadan elde edilen ilan verileri incelendiğinde İstanbul'daki satılık daire ilanlarının ilçelere göre ortalama brüt m2 birim fiyatları ve her ilçedeki ilan sayıları Tablo 1'de gösterildiği gibi hesaplanmıştır. Tablo 1 incelendiğinde; ortalama brüt m2 birim fiyatı en ucuz olan ilçenin 2.456,23 TL ile Arnavutköy ilçesi olduğu, en pahalı ilçenin de 17.309,15 TL ile Beşiktaş olduğu anlașılmaktadır. İstanbul ilinin brüt m2 birim fiyat ortalaması ise 5.107,22 TL olarak hesaplanmiştır.

İstanbul ilindeki satılık dairelerin ilçelere ve oda sayılarına göre ortalama satış fiyatları Tablo 2'de gösterilmektedir. Oda sayısına göre ilçelerdeki satılık dairelerin ortalama fiyatlarına Tablo 2'den bakılacak olursa, 1+1 daireler için ortalama satış fiyatının en ucuz olduğu ilçe 163.671,05 TL ile Sultangazi ilçesi, en pahalı olduğu ilçe ise 873.000,00 TL ile Beşiktaş ilçesidir. İstanbul genelinde 1+1 dairelerin ortalama satış fiyatı ise 352.023,47 TL olarak hesaplanmıştır. Esenyurt 246.432,58 TL ortalama satış fiyatına göre 2+1 dairelerin en ucuz olduğu ilçedir. Buna karşın Sarıyer 1.463.946,49 TL ile 2+1 dairelerin en pahalı ortalama satış fiyatının olduğu ilçedir. 
İstanbul genelindeki 2+1 dairelerin araştırma kapsamındaki ortalama satış fiyatı ise 418.388,77 TL olarak hesaplanmıştır. 3+1 daireler için İstanbul genelindeki ortalama satış fiyatı 796.677,05 TL olarak hesaplanmıştır. 3+1 dairelerin en ucuz olduğu ilçe 339.525,49 TL ile Arnavutköy, en pahalı olduğu ilçe ise 2.570.844,48 TL ile Beşiktaş'tır. 4+1 dairelerin İstanbul genelindeki ortalama satış fiyatı 1.973.434,36 TL'dir. 4+1 dairelerin ortalama satıș fiyatına göre en ucuz olduğu ilçe 342.363,59 TL ile Arnavutköy, en pahalı olduğu ilçe ise 7.495.441,18 TL ile Beşiktaş olarak hesaplanmıştır. İlçelerin genel ortalamasına bakıldığında satılık dairelerin en ucuz olduğu ilçenin 269.604,12 TL ortalama satış fiyatı ile Arnavutköy olduğu, en pahalı ilçenin ise 2.735.397,72 TL ile Beşiktaş olduğu anlaşılmaktadır. İstanbul genelindeki bir dairenin ortalama satış fiyatı da 645.764,03 TL olarak hesaplanmıştır.

Tablo 3. İstanbul'daki Satılık Dairelerin İlçelere Göre Ortalama $\mathrm{m}^{2}$ Birim Fiyatları (Average $\mathrm{m}^{2}$ Prices of Apartments for Sale in Istanbul by Districts)

\begin{tabular}{|c|c|c|c|c|c|}
\hline İlçe Adı & $\begin{array}{r}\text { Ortalama Brüt m}^{2} \\
\text { Birim Fiyatı }\end{array}$ & İlan Sayısı & İlçe Adı & $\begin{array}{r}\text { Ortalama } \\
\text { Brüt } \mathbf{m}^{2} \text { Birim Fiyatı }\end{array}$ & İlan Sayısı \\
\hline Adalar & $7.403,95 \mathrm{TL}$ & 161 & Gaziosmanpaşa & $3.382,19 \mathrm{TL}$ & 992 \\
\hline Arnavutköy & $2.456,23 \mathrm{TL}$ & 986 & Güngören & $3.582,41 \mathrm{TL}$ & 973 \\
\hline Atașehir & $5.195,34 \mathrm{TL}$ & 991 & Kadıköy & $9.711,75 \mathrm{TL}$ & 929 \\
\hline Avcilar & $3.122,60 \mathrm{TL}$ & 989 & Kağıthane & $4.202,98 \mathrm{TL}$ & 959 \\
\hline Bağcılar & $3.558,14 \mathrm{TL}$ & 990 & Kartal & $4.268,39 \mathrm{TL}$ & 995 \\
\hline Bahçelievler & $3.863,80 \mathrm{TL}$ & 991 & Küçükçekmece & $3.895,85 \mathrm{TL}$ & 898 \\
\hline Bakırköy & $11.473,57 \mathrm{TL}$ & 990 & Maltepe & $4.322,94 \mathrm{TL}$ & 921 \\
\hline Başakșehir & $4.615,21 \mathrm{TL}$ & 976 & Pendik & $3.309,98 \mathrm{TL}$ & 804 \\
\hline Bayrampaşa & $4.131,94 \mathrm{TL}$ & 971 & Sancaktepe & $2.715,15 \mathrm{TL}$ & 957 \\
\hline Beşiktaş & $17.309,15 \mathrm{TL}$ & 985 & Sariyer & $13.907,25 \mathrm{TL}$ & 983 \\
\hline Beykoz & $7.956,19 \mathrm{TL}$ & 442 & Silivri & $2.494,98 \mathrm{TL}$ & 937 \\
\hline Beylikdüzü & $2.895,38 \mathrm{TL}$ & 987 & Sultanbeyli & $2.698,36 \mathrm{TL}$ & 899 \\
\hline Beyoğlu & $8.496,03 \mathrm{TL}$ & 969 & Sultangazi & $2.669,35 \mathrm{TL}$ & 991 \\
\hline Büyükçekmece & $3.818,85 \mathrm{TL}$ & 990 & Şile & $3.379,86 \mathrm{TL}$ & 283 \\
\hline Çatalca & $2.685,63 \mathrm{TL}$ & 228 & Şişli & $6.982,16 \mathrm{TL}$ & 979 \\
\hline Çekmeköy & $3.229,32 \mathrm{TL}$ & 993 & Tuzla & $3.406,13 \mathrm{TL}$ & 982 \\
\hline Esenler & $3.106,28 \mathrm{TL}$ & 961 & Ümraniye & $3.964,51 \mathrm{TL}$ & 955 \\
\hline Esenyurt & $2.504,25 \mathrm{TL}$ & 956 & Üsküdar & $6.866,28 \mathrm{TL}$ & 882 \\
\hline Eyüpsultan & $5.304,33 \mathrm{TL}$ & 991 & Zeytinburnu & $5.356,75 \mathrm{TL}$ & 980 \\
\hline Fatih & $4.806,80 \mathrm{TL}$ & 997 & Toplam & $5.107,22 \mathrm{TL}$ & 34.843 \\
\hline
\end{tabular}

Tablo 4. İstanbul'daki Satılık Dairelerin İlçelere Göre Ortalama Satış Fiyatları (Average Sale Prices of Apartments for Sale in Istanbul by Districts)

\begin{tabular}{|c|c|c|c|c|c|}
\hline \multirow[b]{2}{*}{ İlçe Adı } & \multicolumn{4}{|c|}{ Ortalama Satış Fiyatı } & \multirow[b]{2}{*}{ İlçe Ortalaması } \\
\hline & $1+1$ & $2+1$ & $3+1$ & $4+1$ & \\
\hline Adalar & $290.000,00 \mathrm{TL}$ & $665.680,83 \mathrm{TL}$ & $1.022 .374,63 \mathrm{TL}$ & $1.374 .615,38 \mathrm{TL}$ & 962.816,98 TL \\
\hline Arnavutköy & $267.344,59 \mathrm{TL}$ & $247.984,51 \mathrm{TL}$ & $339.525,49 \mathrm{TL}$ & $342.363,59 \mathrm{TL}$ & $269.604,12 \mathrm{TL}$ \\
\hline Ataşehir & $386.287,77 \mathrm{TL}$ & $461.463,43 \mathrm{TL}$ & $790.445,29 \mathrm{TL}$ & $1.382 .738,79 \mathrm{TL}$ & $635.983,19 \mathrm{TL}$ \\
\hline Avcrlar & $232.034,80 \mathrm{TL}$ & $295.213,34 \mathrm{TL}$ & $468.944,44 \mathrm{TL}$ & $852.591,84 \mathrm{TL}$ & 383.124,28 TL \\
\hline Bağcllar & $297.257,69 \mathrm{TL}$ & $341.376,30 \mathrm{TL}$ & $523.442,24 \mathrm{TL}$ & $621.657,89 \mathrm{TL}$ & $405.988,13 \mathrm{TL}$ \\
\hline Bahçelievler & $230.803,28 \mathrm{TL}$ & $342.099,81 \mathrm{TL}$ & $550.559,79 \mathrm{TL}$ & $788.021,74 \mathrm{TL}$ & $429.096,14 \mathrm{TL}$ \\
\hline Bakırköy & $630.627,45 \mathrm{TL}$ & $933.304,64 \mathrm{TL}$ & $1.770 .800,30 \mathrm{TL}$ & 3.417.671,14 TL & 1.632.169,17 TL \\
\hline Başakșehir & $308.338,24 \mathrm{TL}$ & $441.479,74 \mathrm{TL}$ & $718.446,72 \mathrm{TL}$ & $1.219 .398,77 \mathrm{TL}$ & $659.815,90 \mathrm{TL}$ \\
\hline Bayrampaşa & $309.297,56 \mathrm{TL}$ & $359.659,98 \mathrm{TL}$ & $751.842,47 \mathrm{TL}$ & $838.437,50 \mathrm{TL}$ & $447.868,49 \mathrm{TL}$ \\
\hline Beşiktaş & $873.000,00 \mathrm{TL}$ & $1.341 .526,95 \mathrm{TL}$ & $2.570 .844,48 \mathrm{TL}$ & 7.495.441,18 TL & $2.735 .397,72 \mathrm{TL}$ \\
\hline Beykoz & $703.764,71 \mathrm{TL}$ & 729.606,19 TL & $1.085 .253,46 \mathrm{TL}$ & $2.838 .962,26 \mathrm{TL}$ & $1.200 .936,25 \mathrm{TL}$ \\
\hline Beylikdüzü & $203.280,23 \mathrm{TL}$ & $288.038,56 \mathrm{TL}$ & $528.386,79 \mathrm{TL}$ & $916.571,43 \mathrm{TL}$ & $390.716,34 \mathrm{TL}$ \\
\hline Beyoğlu & $577.726,03 \mathrm{TL}$ & $744.219,73 \mathrm{TL}$ & $1.296 .718,12 \mathrm{TL}$ & $2.573 .275,86 \mathrm{TL}$ & $975.342,94 \mathrm{TL}$ \\
\hline Büyükçekmece & $266.524,19 \mathrm{TL}$ & $376.039,10 \mathrm{TL}$ & $629.378,15 \mathrm{TL}$ & $1.254 .075,00 \mathrm{TL}$ & $552.752,00 \mathrm{TL}$ \\
\hline Çatalca & $201.600,00 \mathrm{TL}$ & $272.307,28 \mathrm{TL}$ & $359.942,31 \mathrm{TL}$ & $441.000,00 \mathrm{TL}$ & $314.548,22 \mathrm{TL}$ \\
\hline Çekmeköy & $221.852,46 \mathrm{TL}$ & $312.760,43 \mathrm{TL}$ & $467.441,39 \mathrm{TL}$ & $682.105,54 \mathrm{TL}$ & $364.870,19 \mathrm{TL}$ \\
\hline Esenler & $199.522,12 \mathrm{TL}$ & $283.869,24 \mathrm{TL}$ & $396.934,90 \mathrm{TL}$ & $434.714,29 \mathrm{TL}$ & $306.511,06 \mathrm{TL}$ \\
\hline Esenyurt & $213.055,73 \mathrm{TL}$ & $246.432,58 \mathrm{TL}$ & $379.778,13 \mathrm{TL}$ & $686.500,00 \mathrm{TL}$ & $276.956,51 \mathrm{TL}$ \\
\hline Eyüpsultan & $397.816,67 \mathrm{TL}$ & $445.032,44 \mathrm{TL}$ & $943.786,43 \mathrm{TL}$ & $1.855 .061,22 \mathrm{TL}$ & $693.025,50 \mathrm{TL}$ \\
\hline Fatih & $261.687,08 \mathrm{TL}$ & $407.478,33 \mathrm{TL}$ & $751.457,04 \mathrm{TL}$ & 1.011.641,03 TL & 498.371,39 TL \\
\hline Gaziosmanpaşa & $315.843,75 \mathrm{TL}$ & $322.885,35 \mathrm{TL}$ & $536.708,03 \mathrm{TL}$ & $657.171,43 \mathrm{TL}$ & 376.118,35 TL \\
\hline Güngören & $239.526,79 \mathrm{TL}$ & $325.632,41 \mathrm{TL}$ & $482.840,26 \mathrm{TL}$ & $557.302,33 \mathrm{TL}$ & $384.832,79 \mathrm{TL}$ \\
\hline Kadıköy & $448.640,00 \mathrm{TL}$ & $696.732,62 \mathrm{TL}$ & $1.308 .316,62 \mathrm{TL}$ & 2.452.581,08 TL & $1.330 .092,21 \mathrm{TL}$ \\
\hline Kağıthane & $294.934,51 \mathrm{TL}$ & 385.588,01 TL & $544.157,58 \mathrm{TL}$ & $639.046,51 \mathrm{TL}$ & $412.956,04 \mathrm{TL}$ \\
\hline Kartal & $436.300,00 \mathrm{TL}$ & $401.148,89 \mathrm{TL}$ & $572.521,60 \mathrm{TL}$ & $1.068 .515,15 \mathrm{TL}$ & $500.131,34 \mathrm{TL}$ \\
\hline Küçükçekmece & $300.062,04 \mathrm{TL}$ & $339.473,88 \mathrm{TL}$ & $600.714,99 \mathrm{TL}$ & $911.838,46 \mathrm{TL}$ & $443.114,44 \mathrm{TL}$ \\
\hline Maltepe & $310.911,39 \mathrm{TL}$ & 402.426,18 TL & $572.937,38 \mathrm{TL}$ & $838.316,67 \mathrm{TL}$ & $477.217,71 \mathrm{TL}$ \\
\hline Pendik & $245.099,81 \mathrm{TL}$ & $313.771,52 \mathrm{TL}$ & $441.613,11 \mathrm{TL}$ & $867.741,38 \mathrm{TL}$ & $378.836,47 \mathrm{TL}$ \\
\hline Sancaktepe & $248.757,41 \mathrm{TL}$ & $282.510,47 \mathrm{TL}$ & $371.575,60 \mathrm{TL}$ & $350.250,00 \mathrm{TL}$ & $317.196,85 \mathrm{TL}$ \\
\hline Sarıyer & 793.621,62 TL & $1.463 .946,49 \mathrm{TL}$ & $2.509 .859,76 \mathrm{TL}$ & $4.250 .149,35 \mathrm{TL}$ & $2.320 .055,36 \mathrm{TL}$ \\
\hline Silivri & $172.108,70 \mathrm{TL}$ & $249.133,20 \mathrm{TL}$ & $364.696,98 \mathrm{TL}$ & $637.592,59 \mathrm{TL}$ & $315.990,37 \mathrm{TL}$ \\
\hline Sultanbeyli & $231.357,73 \mathrm{TL}$ & $268.122,52 \mathrm{TL}$ & $361.436,25 \mathrm{TL}$ & $386.437,50 \mathrm{TL}$ & $303.588,21 \mathrm{TL}$ \\
\hline Sultangazi & $163.671,05 \mathrm{TL}$ & $272.103,64 \mathrm{TL}$ & $381.186,98 \mathrm{TL}$ & $389.461,54 \mathrm{TL}$ & $287.392,93 \mathrm{TL}$ \\
\hline Şile & $230.285,71 \mathrm{TL}$ & $326.818,74 \mathrm{TL}$ & $423.428,57 \mathrm{TL}$ & $577.727,27 \mathrm{TL}$ & $366.413,12 \mathrm{TL}$ \\
\hline Şişli & $503.874,59 \mathrm{TL}$ & $630.149,90 \mathrm{TL}$ & $1.200 .121,50 \mathrm{TL}$ & $1.902 .569,44 \mathrm{TL}$ & $869.787,42 \mathrm{TL}$ \\
\hline Tuzla & $234.141,46 \mathrm{TL}$ & $328.989,89 \mathrm{TL}$ & $487.068,42 \mathrm{TL}$ & $709.574,98 \mathrm{TL}$ & $384.107,38 \mathrm{TL}$ \\
\hline Ümraniye & $284.250,00 \mathrm{TL}$ & $368.168,65 \mathrm{TL}$ & $542.036,83 \mathrm{TL}$ & $777.735,85 \mathrm{TL}$ & $436.386,22 \mathrm{TL}$ \\
\hline Üsküdar & $330.292,31 \mathrm{TL}$ & $536.167,87 \mathrm{TL}$ & $939.290,95 \mathrm{TL}$ & $2.371 .600,00 \mathrm{TL}$ & $848.565,42 \mathrm{TL}$ \\
\hline Zeytinburnu & $418.254,67 \mathrm{TL}$ & $457.864,87 \mathrm{TL}$ & $863.518,03 \mathrm{TL}$ & 1.558.984,62 TL & $649.866,50 \mathrm{TL}$ \\
\hline Genel Ortalama & $352.023,47$ TL & 418.388,77 TL & $796.677,05$ TL & $1.973 .434,36 \mathrm{TL}$ & $645.764,03 \mathrm{TL}$ \\
\hline
\end{tabular}


İstanbul'daki satılık dairelerin ilçelere göre bina yaşları Tablo 3'te sunulmuştur. Tablo 3 incelendiğinde; Adalar, Ataşehir, Başakşehir, Beşiktaş, Beykoz, Beyoğlu, Büyükçekmece, Fatih, Güngören, Sarıyer ve Zeytinburnu haricindeki tüm ilçelerde en fazla satılık dairelerin sıfır daireler olduğu anlaşılmaktadır. İlçelerdeki satılık dairelerin ortalama yaşlarına bakıldığında en yaşlı binaların 24,27 yaş ortalamasıyla Adalar ilçesinde olduğu görülmektedir. Buna karşın en yeni daireler 1,69 yaş ortalamasıyla Arnavutköy ilçesinde bulunmaktadır. Araştırma verilerine göre İstanbul ilindeki incelenen satılık dairelerin yaş ortalaması ise 8,49 olarak hesaplanmiştır.

İstanbul'daki satılık dairelerin ısınma türleri Tablo 4'te gösterilmiştir. Tablo 4 incelendiğinde, dairelerin büyük çoğunluğunun $(\%$ 79,35) ısınma yöntemi olarak doğalgazı kullandığı, dairelerin yaklaşık \% 20'sinin ise merkezi sistemle ısıtıldığı anlaşılmaktadır. Ancak ilan verilerinde merkezi sistemde kömür, doğalgaz vb. hangi yakıt türünün kullanıldığı belirtilmemiştir. Genel olarak tüm ilçelerde dairelerin çoğunluğunun doğalgaz ve bireysel kombiyle ısıtılmasına karşın sadece Başakşehir ilçesinde dairelerin \% 65,73 gibi büyük bir kısmının pay ölçer ile merkezi sistemde ısıtıldığı görülmektedir. İlçeler nezdinde doğalgazdan sonra ısıtmada en çok Adalar'da dairelerin \% 16,15'inde klima kullanılmaktadır. Buna karşın İstanbul genelinde ısıtmada en az kullanılan yöntemin klima olduğu görülmektedir $(\%, 0,15)$.

\subsection{Konut Alma Karar Destek Modeli Uygulama Sonuçları (Housing Decision Support Model Implementation Results)}

40 adet örnek ilan verisi üzerinden yapılan uygulamada her bir ilan kaydı bir alternatif olarak değerlendirilerek A1,A2,„,A40 şeklinde isimlendirilmiştir. Konut alma karar modelinin örnek ilan alternatiflerine uygulanması sonrasında elde edilen ana kriterlere ve amaç fonksiyonuna ait bulunan değerler Tablo 5'te gösterilmiştir. Alternatiflerin amaç fonksiyonu değerine göre büyükten küçüğe doğru sıralanmış hali ise Tablo 6'da gösterilmiştir. Tablo 6 incelendiğinde, amaç fonksiyonuna (F) göre alternatifler büyükten küçüğe doğru sıralandığında, girilen ağırlık katsayılarına göre en iyi değere sahip alternatifin A1 ilanındaki daire olduğu görülmektedir. İkinci en iyi daire A11 ilanındaki dairedir. Sonraki en iyi dairelere ait ilanlar sırasıyla A28, A24 ve A3 olarak devam etmektedir. Girilen örnek ağırlık katsayılarına göre beklentileri karşılamada en yetersiz kalan dairenin ise A25 ilanı olduğu anlaşılmaktadır.

Tablo 5. İstanbul'daki Satılık Dairelerin İlçelere Göre Bina Yașı (Age of Apartments for Sale in Istanbul by District)

\begin{tabular}{|c|c|c|c|c|c|c|c|c|c|c|c|c|}
\hline \multirow{2}{*}{ İlçe adı } & \multicolumn{12}{|c|}{ Bina Yașı } \\
\hline & $\mathbf{0}$ & 1 & 2 & 3 & 4 & $5-10$ & 11-15 & $16-20$ & $21-25$ & $26-30$ & $31+$ & Ort. \\
\hline Adalar & 1 & - & - & - & 2 & 2 & - & 18 & 53 & 61 & 24 & 24,27 \\
\hline Arnavutköy & 615 & 68 & 52 & 52 & 48 & 118 & 25 & 7 & 1 & - & - & 1,69 \\
\hline Ataşehir & 204 & 57 & 48 & 34 & 121 & 316 & 61 & 70 & 47 & 27 & 6 & 6,57 \\
\hline Avcılar & 335 & 35 & 33 & 46 & 77 & 186 & 33 & 82 & 103 & 50 & 9 & 7,44 \\
\hline Bağcılar & 225 & 48 & 53 & 51 & 78 & 173 & 60 & 107 & 141 & 46 & 8 & 8,88 \\
\hline Bahçelievler & 261 & 24 & 31 & 26 & 33 & 139 & 50 & 70 & 141 & 156 & 60 & 12,26 \\
\hline Bakırköy & 261 & 42 & 35 & 22 & 30 & 73 & 81 & 31 & 89 & 121 & 205 & 14,16 \\
\hline Başakşehir & 206 & 106 & 89 & 102 & 100 & 238 & 74 & 44 & 15 & 2 & - & 4,55 \\
\hline Bayrampaşa & 327 & 46 & 28 & 44 & 81 & 154 & 43 & 67 & 87 & 65 & 29 & 7,96 \\
\hline Beşiktaş & 110 & 27 & 17 & 25 & 56 & 59 & 30 & 94 & 132 & 220 & 215 & 18,68 \\
\hline Beykoz & 16 & 4 & 5 & 2 & 21 & 82 & 91 & 112 & 43 & 35 & 31 & 14,65 \\
\hline Beylikdüzü & 563 & 41 & 47 & 54 & 97 & 101 & 38 & 38 & 8 & - & - & 2,60 \\
\hline Beyoğlu & 144 & 31 & 18 & 18 & 29 & 125 & 48 & 71 & 71 & 96 & 318 & 17,65 \\
\hline Büyükçekmece & 252 & 31 & 34 & 45 & 64 & 266 & 70 & 94 & 73 & 31 & 30 & 8,01 \\
\hline Çatalca & 93 & 10 & 12 & 8 & 15 & 31 & 19 & 14 & 14 & 9 & 3 & 6,21 \\
\hline Çekmeköy & 371 & 91 & 64 & 62 & 106 & 218 & 58 & 21 & 1 & 1 & - & 3,26 \\
\hline Esenler & 218 & 35 & 52 & 66 & 67 & 160 & 63 & 98 & 149 & 47 & 6 & 9,08 \\
\hline Esenyurt & 321 & 88 & 77 & 88 & 125 & 203 & 24 & 24 & 6 & - & - & 3,19 \\
\hline Eyüpsultan & 395 & 75 & 58 & 45 & 77 & 233 & 68 & 14 & 8 & 10 & 8 & 3,82 \\
\hline Fatih & 66 & 8 & 15 & 7 & 12 & 36 & 18 & 47 & 75 & 288 & 425 & 24,44 \\
\hline Gaziosmanpaşa & 279 & 28 & 46 & 43 & 76 & 171 & 81 & 136 & 93 & 28 & 11 & 8,08 \\
\hline Güngören & 72 & 22 & 17 & 16 & 36 & 76 & 19 & 63 & 265 & 261 & 126 & 19,44 \\
\hline Kadıköy & 439 & 97 & 66 & 27 & 12 & 23 & 9 & 20 & 63 & 96 & 77 & 7,95 \\
\hline Kağıthane & 276 & 75 & 79 & 78 & 152 & 144 & 33 & 75 & 35 & 7 & 5 & 4,93 \\
\hline Kartal & 385 & 71 & 60 & 40 & 63 & 150 & 33 & 71 & 72 & 38 & 12 & 6,09 \\
\hline Küçükçekmece & 255 & 81 & 55 & 53 & 84 & 183 & 27 & 77 & 56 & 19 & 8 & 6,03 \\
\hline Maltepe & 325 & 58 & 59 & 45 & 76 & 113 & 18 & 57 & 82 & 64 & 24 & 7,36 \\
\hline Pendik & 294 & 60 & 30 & 27 & 61 & 198 & 52 & 39 & 27 & 13 & 3 & 4,93 \\
\hline Sancaktepe & 357 & 120 & 92 & 101 & 128 & 134 & 19 & 6 & - & - & - & 2,35 \\
\hline Sarıyer & 126 & 99 & 75 & 83 & 85 & 162 & 69 & 117 & 73 & 48 & 46 & 9,16 \\
\hline Silivri & 338 & 62 & 43 & 43 & 62 & 166 & 52 & 89 & 48 & 28 & 6 & 6,04 \\
\hline Sultanbeyli & 449 & 153 & 83 & 62 & 71 & 18 & 20 & 35 & 6 & 2 & - & 2,13 \\
\hline Sultangazi & 330 & 38 & 47 & 49 & 82 & 212 & 110 & 80 & 27 & 15 & 1 & 5,64 \\
\hline Şile & 92 & 5 & 13 & 9 & 16 & 36 & 21 & 46 & 28 & 16 & 1 & 8,66 \\
\hline Şiş̧li & 192 & 57 & 44 & 34 & 51 & 100 & 69 & 82 & 81 & 102 & 167 & 13,44 \\
\hline Tuzla & 368 & 82 & 67 & 70 & 127 & 171 & 36 & 37 & 8 & 9 & 7 & 3,73 \\
\hline Ümraniye & 290 & 42 & 45 & 40 & 77 & 271 & 103 & 57 & 20 & 8 & 2 & 5,35 \\
\hline Üsküdar & 273 & 33 & 31 & 26 & 43 & 82 & 34 & 78 & 84 & 106 & 92 & 11,59 \\
\hline Zeytinburnu & 121 & 73 & 35 & 16 & 53 & 48 & 48 & 150 & 250 & 62 & 7 & 12,16 \\
\hline Toplam & 10245 & 2123 & 1755 & 1659 & 5488 & 1807 & 2438 & 2575 & 2187 & 1972 & 1807 & 8,49 \\
\hline
\end{tabular}


Tablo 6. İstanbul'daki Satılık Dairelerin Isınma Türüne Göre Yüzde Dağılımı (Percentage Distribution of Apartments for Sale

\begin{tabular}{|c|c|c|c|c|c|c|c|c|}
\hline İlçe Adı & $\begin{array}{l}\text { Doğalgaz } \\
\text { (Kombi) }\end{array}$ & $\begin{array}{l}\text { Doğalgaz } \\
\text { Sobası } \\
\end{array}$ & $\begin{array}{l}\text { Kat } \\
\text { Kaloriferi }\end{array}$ & Klima & $\begin{array}{l}\text { Merkezi } \\
\text { Sistem } \\
\end{array}$ & $\begin{array}{l}\text { Merkezi Sistem (Pay } \\
\text { Ölçer) }\end{array}$ & Soba & $\begin{array}{l}\text { Genel } \\
\text { Toplam }\end{array}$ \\
\hline Adalar & 76,92 & 1,54 & 2,31 & 16,15 & 0,77 & 0,00 & 2,31 & 100,00 \\
\hline Arnavutköy & 92,25 & 0,71 & 0,82 & 0,00 & 2,45 & 3,77 & 0,00 & 100,00 \\
\hline Ataşehir & 70,77 & 0,31 & 0,92 & 0,00 & 2,95 & 24,85 & 0,20 & 100,00 \\
\hline Avcilar & 82,41 & 0,61 & 0,61 & 0,00 & 1,33 & 15,03 & 0,00 & 100,00 \\
\hline Bağcılar & 78,07 & 1,13 & 1,02 & 0,00 & 0,51 & 18,03 & 1,23 & 100,00 \\
\hline Bahçelievler & 92,32 & 1,43 & 0,31 & 0,10 & 2,35 & 3,17 & 0,31 & 100,00 \\
\hline Bakırköy & 67,37 & 0,42 & 0,21 & 0,00 & 19,62 & 12,38 & 0,00 & 100,00 \\
\hline Başakşehir & 28,44 & 0,21 & 0,42 & 0,00 & 5,10 & 65,73 & 0,10 & 100,00 \\
\hline Bayrampașa & 85,95 & 4,30 & 1,47 & 0,10 & 0,10 & 7,86 & 0,21 & 100,00 \\
\hline Beşiktaş & 53,69 & 0,21 & 0,62 & 0,21 & 27,41 & 17,86 & 0,00 & 100,00 \\
\hline Beykoz & 94,77 & 0,71 & 0,24 & 0,24 & 2,85 & 1,19 & 0,00 & 100,00 \\
\hline Beylikdüzü & 83,33 & 0,10 & 0,71 & 0,00 & 1,73 & 14,13 & 0,00 & 100,00 \\
\hline Beyoğlu & 90,61 & 0,53 & 0,00 & 0,32 & 3,16 & 3,90 & 1,48 & 100,00 \\
\hline Büyükçekmece & 88,61 & 0,62 & 0,62 & 0,00 & 3,31 & 6,42 & 0,41 & 100,00 \\
\hline Çatalca & 96,86 & 0,90 & 0,00 & 0,00 & 0,00 & 0,45 & 1,79 & 100,00 \\
\hline Çekmeköy & 85,89 & 0,61 & 0,51 & 0,00 & 0,51 & 12,39 & 0,10 & 100,00 \\
\hline Esenler & 84,05 & 4,59 & 0,10 & 0,10 & 0,73 & 9,70 & 0,73 & 100,00 \\
\hline Esenyurt & 71,17 & 0,74 & 0,64 & 0,00 & 2,66 & 24,79 & 0,00 & 100,00 \\
\hline Eyüpsultan & 78,83 & 0,31 & 0,51 & 0,41 & 0,62 & 19,32 & 0,00 & 100,00 \\
\hline Fatih & 86,49 & 7,27 & 1,94 & 0,31 & 1,13 & 1,54 & 1,33 & 100,00 \\
\hline Gaziosmanpaşa & 86,03 & 2,55 & 0,20 & 0,10 & 2,75 & 8,26 & 0,10 & 100,00 \\
\hline Güngören & 85,91 & 3,34 & 0,31 & 0,21 & 6,05 & 3,44 & 0,73 & 100,00 \\
\hline Kadıköy & 53,53 & 0,67 & 0,11 & 0,11 & 12,77 & 32,70 & 0,11 & 100,00 \\
\hline Kağıthane & 84,28 & 0,52 & 0,31 & 0,00 & 1,78 & 12,79 & 0,31 & 100,00 \\
\hline Kartal & 73,31 & 0,10 & 0,62 & 0,10 & 3,12 & 22,74 & 0,00 & 100,00 \\
\hline Küçükçekmece & 74,71 & 1,26 & 0,69 & 0,00 & 2,75 & 20,37 & 0,23 & 100,00 \\
\hline Maltepe & 79,16 & 0,55 & 0,00 & 0,11 & 3,66 & 16,52 & 0,00 & 100,00 \\
\hline Pendik & 80,61 & 0,51 & 0,64 & 0,00 & 1,28 & 16,71 & 0,26 & 100,00 \\
\hline Sancaktepe & 86,77 & 0,32 & 0,42 & 0,00 & 0,32 & 12,17 & 0,00 & 100,00 \\
\hline Sarıyer & 47,06 & 0,22 & 0,22 & 0,11 & 11,10 & 40,95 & 0,33 & 100,00 \\
\hline Silivri & 88,61 & 0,44 & 0,66 & 0,22 & 0,44 & 9,20 & 0,44 & 100,00 \\
\hline Sultanbeyli & 80,16 & 0,33 & 0,33 & 0,00 & 1,00 & 17,61 & 0,56 & 100,00 \\
\hline Sultangazi & 93,50 & 1,32 & 0,61 & 0,00 & 0,41 & 4,07 & 0,10 & 100,00 \\
\hline Şile & 94,42 & 0,37 & 0,74 & 0,00 & 2,60 & 1,12 & 0,74 & 100,00 \\
\hline Şişli & 79,90 & 0,21 & 0,83 & 0,21 & 11,81 & 6,94 & 0,10 & 100,00 \\
\hline Tuzla & 58,62 & 0,00 & 0,72 & 0,00 & 1,85 & 38,40 & 0,41 & 100,00 \\
\hline Ümraniye & 84,04 & 0,11 & 0,74 & 0,00 & 1,27 & 13,85 & 0,00 & 100,00 \\
\hline Üsküdar & 86,36 & 1,05 & 0,23 & 0,12 & 5,36 & 6,88 & 0,00 & 100,00 \\
\hline Zeytinburnu & 75,85 & 2,38 & 0,73 & 0,21 & 1,76 & 17,93 & 1,14 & 100,00 \\
\hline Genel Toplam & 78,21 & 1,14 & 0,57 & 0,15 & 4,06 & 15,53 & 0,33 & 100,00 \\
\hline
\end{tabular}

Tablo 7. Alternatifler İçin Hesaplanan Fonksiyon Değerleri (Calculated Function Values for Alternatives)

\begin{tabular}{|c|c|c|c|c|c|c|}
\hline Alternatif & $B(X)$ & $S(X)$ & $T(X)$ & $H(X)$ & $I(X)$ & $F(X)$ \\
\hline A1 & 0,45 & 0,3 & 0,639 & 0,6 & 0,96 & 0,6087 \\
\hline A2 & 0,438333 & 0,65 & 0,44 & 0,6 & 0,15 & 0,4185 \\
\hline A3 & 0,391989 & 0,1 & 0,619 & 0,6 & 0,38 & 0,449297 \\
\hline A4 & 0,269891 & 0,15 & 0,22 & 0,4 & 0,24 & 0,249967 \\
\hline A5 & 0,387463 & 0 & 0,219 & 0,4 & 0,28 & 0,277939 \\
\hline A6 & 0,297741 & 0,3 & 0,12 & 0,6 & 0,25 & 0,265322 \\
\hline A7 & 0,313333 & 0,2 & 0,043 & 0,64 & 0,17 & 0,2249 \\
\hline A8 & 0,257269 & 0 & 0,219 & 0,6 & 0,45 & 0,292881 \\
\hline A9 & 0,223755 & 0,05 & 0,219 & 0,4 & 0,24 & 0,225826 \\
\hline A10 & 0,180667 & 0,5 & 0,44 & 0 & 0,28 & 0,2922 \\
\hline A11 & 0,791667 & 0,25 & 0,719 & 0 & 0,31 & 0,5402 \\
\hline A12 & 0,496259 & 0 & 0,619 & 0,52 & 0,16 & 0,418578 \\
\hline A13 & 0,394664 & 0,2 & 0,222 & 0,2 & 0,44 & 0,312999 \\
\hline A14 & 0,431806 & 0,3 & 0,12 & 0,2 & 0,56 & 0,327542 \\
\hline A15 & 0,548455 & 0,05 & 0,222 & 0 & 0,38 & 0,312136 \\
\hline A16 & 0,515 & 0 & 0,12 & 0 & 0,18 & 0,2265 \\
\hline A17 & 0,554164 & 0 & 0,319 & 0 & 0,18 & 0,297949 \\
\hline A18 & 0,351765 & 0,15 & 0,619 & 0 & 0,11 & 0,328229 \\
\hline A19 & 0,384111 & 0,35 & 0,638 & 0,24 & 0,2 & 0,405633 \\
\hline A20 & 0,366 & 0,25 & 0,44 & 0,2 & 0,17 & 0,3208 \\
\hline A21 & 0,494561 & 0 & 0,12 & 0,3 & 0,1 & 0,234368 \\
\hline A22 & 0,452561 & 0,2 & 0,318 & 0 & 0,16 & 0,283168 \\
\hline A23 & 0,441111 & 0,15 & 0,22 & 0,4 & 0,16 & 0,285333 \\
\hline A24 & 0,430485 & 0,2 & 0,222 & 0,4 & 1 & 0,455745 \\
\hline A25 & 0,365391 & 0,05 & 0,12 & 0,44 & 0,04 & 0,202617 \\
\hline A26 & 0,436485 & 0 & 0,443 & 0,64 & 0,12 & 0,351845 \\
\hline A27 & 0,466485 & 0,2 & 0,718 & 0,6 & 0,02 & 0,439345 \\
\hline A28 & 0,458667 & 0 & 0,718 & 0,6 & 0,32 & 0,477 \\
\hline A29 & 0,364286 & 0,35 & 0,417 & 0 & 0,57 & 0,383386 \\
\hline A30 & 0,423485 & 0,15 & 0,12 & 0 & 0,25 & 0,228045 \\
\hline A31 & 0,458667 & 0 & 0,219 & 0 & 0,17 & 0,2373 \\
\hline A32 & 0,354561 & 0,2 & 0,319 & 0 & 0,16 & 0,254068 \\
\hline A33 & 0,379856 & 0,3 & 0,52 & 0,2 & 0,25 & 0,369957 \\
\hline A34 & 0,44 & 0,1 & 0,238 & 0,3 & 0,08 & 0,2594 \\
\hline A35 & 0,370485 & 0,1 & 0,219 & 0,2 & 1 & 0,406845 \\
\hline A36 & 0,432 & 0 & 0,222 & 0,4 & 0,2 & 0,2762 \\
\hline A37 & 0,430393 & 0,15 & 0,44 & 0,4 & 0 & 0,316118 \\
\hline A38 & 0,306987 & 0,1 & 0,318 & 0,5 & 0 & 0,247496 \\
\hline A39 & 0,44 & 0,35 & 0,322 & 0,6 & 0,52 & 0,4276 \\
\hline A40 & 0,326582 & 0,5 & 0,622 & 0,2 & 0,29 & 0,412575 \\
\hline
\end{tabular}


Tablo 8. Alternatiflerin Amaç Fonksiyonu Değerleri ve Sıralı Karar Tablosu (Objective Function Values of Alternatives and

\begin{tabular}{|c|c|c|c|c|c|}
\hline & & & & & \\
\hline Sira No & $F(X)$ & Alternatif & Sira No & $F(X)$ & Alternatif \\
\hline 1 & 0,6087 & A1 & 21 & 0,31214 & A15 \\
\hline 2 & 0,5402 & A11 & 22 & 0,29795 & A17 \\
\hline 3 & 0,477 & A28 & 23 & 0,29288 & A8 \\
\hline 4 & 0,455745 & A24 & 24 & 0,2922 & A10 \\
\hline 5 & 0,449297 & A3 & 25 & 0,28533 & A23 \\
\hline 6 & 0,439345 & A27 & 26 & 0,28317 & $\mathrm{~A} 22$ \\
\hline 7 & 0,4276 & A39 & 27 & 0,27794 & A5 \\
\hline 8 & 0,418578 & A12 & 28 & 0,2762 & A36 \\
\hline 9 & 0,4185 & $\mathrm{x} 2$ & 29 & 0,26532 & A6 \\
\hline 10 & 0,412575 & A40 & 30 & 0,2594 & A34 \\
\hline 11 & 0,406845 & A35 & 31 & 0,25407 & A32 \\
\hline 12 & 0,405633 & A19 & 32 & 0,24997 & A4 \\
\hline 13 & 0,383386 & A29 & 33 & 0,2475 & A38 \\
\hline 14 & 0,369957 & A33 & 34 & 0,2373 & A31 \\
\hline 15 & 0,351845 & A26 & 35 & 0,23437 & $\mathrm{~A} 21$ \\
\hline 16 & 0,328229 & A18 & 36 & 0,22805 & A30 \\
\hline 17 & 0,327542 & A14 & 37 & 0,2265 & A16 \\
\hline 18 & 0,3208 & A20 & 38 & 0,22583 & A9 \\
\hline 19 & 0,316118 & A37 & 39 & 0,2249 & A7 \\
\hline 20 & 0,312999 & A13 & 40 & 0,20262 & A25 \\
\hline
\end{tabular}

\section{Araştırma Bulguları (Research Findings)}

İş hayatında ve günlük hayatta insanlar birtakım kararları vermekte çeșitli sorunlar yaşamakta ve yanlış bir karar vermekten çekindikleri için de çoğu zaman önemli konularda karar vermeleri gerekirken kararsızlık yaşamaktadır. Konut alma da insanların birikiminin büyüklüğüne, ödeme gücüne ve konuta dair birçok özelliğe bağlı olarak verilecek bir karar olduğu için günlük hayatta çoğu insanın yaşadığı karar problemlerinin bașında gelmektedir. Yapılan çalışmada konut alma problemi için insanların alternatif konutları kendi önceliklerine göre matematiksel bir karar modeli ile sıralayarak beklentilerine uygun konutlara karar vermelerini kolaylaştıracak bir karar destek modeli önerilmiştir. Önerilen karar destek modeli doğrusal bir karar modeline dayanmaktadır. Doğrusal karar modeli; amaç fonksiyonunun maksimizasyonunu sağlayan ana kriterler ve alt kriterlerin ağırlıklandırılmış toplamını alma esasına dayanır. Çalışmada önerilen doğrusal karar modeli beş ana kritere ait toplam 29 kriterden oluşmaktadır. Kriterlerin yedisi, 27 adet alt kriterin hesaplanmasından elde edilmektedir. Konut alma problemini ele alma bakımından yapılan çalışmada önerilen matematiksel model ve kullanılan kriterler bu alandaki geçmiş çalışmalara nazaran oldukça yeni ve özgün niteliktedir. Ayrıca yapılan çalışmada karar modelinin uygulanmasına ek olarak İstanbul ilinin 39 ilçesine ait internet sitelerindeki açık kaynaklardan toplam 34.843 adet ilandan oluşan bir veri seti oluşturulmuş olup İstanbul ilinin ilçelerine göre genel bir konut profili de çıkarılmış, ilçelere, oda sayılarına göre dairelerin ortalama fiyatları, ısınma türleri, bina yaşları hesaplanmıştır. Bulgulara göre genel olarak İstanbul'un en pahalı ilçesi Beşiktaş olarak karşımıza çıkmaktadır. En ucuz daire fiyatlarının olduğu ilçeler ise sırasıyla Arnavutköy, Sultangazi ve Esenyurt ilçeleri olarak görülmüştür. Yapılan çalışma bir metropol şehirdeki satılık daire ilanlarıyla ilgili veri seti oluşturma ve kentin konut profilini ortaya çıkarma açısından da yenilikçi ve özgündür. Buradaki çalışmaya benzer şekilde Fuzzy TOPSIS yaklaşımı da faktörleri önceliklendirmede kullanılmaktadır (Rafi vd., 2020). Bunların dışında çok kriterli karar destek sistemlerinde PROMETHEE (Tian, Xu ve Gu, 2019), ELECTRE (Jahan ve Zavadskas, 2019), VIKOR (Fei, Deng ve Hu, 2019), AHP (Ecer, 2020) ve KEMIRA (Sariçali ve Kundakci, 2019) gibi çeșitli modeller de kullanılmaktadır. Buradaki çalışma Fuzzy TOPSIS modeli ile kısmi bir benzerlik göstermektedir. Fuzzy TOPSIS modellerinde de alternatifler arasındaki kararlar verilirken her bir ölçütün önem dereceleri net ve kesindir. Yine Fuzzy TOPSIS modelinde de ideal çözüme yakınlığı gösteren bir indeks kullanılır ve bu indeksin maksimum olduğu alternatif tercih edilir (Masud ve Ravindran, 2008). ELECTRE yönteminin ise iki alternatifi karşılaştırması nedeniyle buradaki çalışmadan farklı özelliği vardır. PROMETHEE modelinde de sınırlı sayıda alternatif için birbiriyle çelişen ölçütlerin karşılaștırılması yaklaşımı vardır (Liu, Cheng ve Zhang, 2019). Bu anlamda buradaki çalıșma ile bir kısım benzerlikler taşıdığı söylenebilir. Buradaki çalışmanın farklılı̆̆ı ise hem ölçütlerin her birine yönelik bir ağırlık verilebilmesi hem de bu ölçütlerin yer aldığı gruba bir ağırlık verilebilmesidir. Buradaki bu hiyerarşik yapı AHP modeli ile de benzerlik göstermektedir (Calabrese vd., 2019).

Bu çalışmada karar modelindeki ağırlık katsayıları örnek olarak kullanılmıștır. Sonraki çalışmalarda ağırlık katsayıları belirli bir katılımcı grubunun taleplerine göre hesaplanabilir. Yapay sinir ağları, genetik algoritma gibi yapay zekâ teknikleri kullanılarak uygun ağırlık katsayıları belirlenebilir. Ayrıca konut ilanlarının yayınlandığı web sayfalarına önerilen karar destek modeli entegre edilerek insanların ilan araştırırken sadece filtreleme yapmaları yerine istediği kritere istediği ağırlık katsayılarını girerek kendi beklentilerine uygun olan ilanların önceliklerine göre sıralanması sağlanabilir. 


\section{Çıkar Çatışması (Conflict of Interest)}

Yazarlar tarafından herhangi bir çıkar çatışması beyan edilmemiştir. No conflict of interest was declared by the authors.

\section{Kaynaklar (References)}

Aktürk, E., ve Tekman, N., 2016. Konut Talebi Ve Erzurum Kent Merkezinde Tüketicilerin Konut Edinme Kararlarını Etkileyen Faktörler. Atatürk Üniversitesi İktisadi ve İdari Bilimler Dergisi, 30(2), 432-440.

Alaybeyoğlu, A., Kılıç, U., İregöl, A., Konbul, Y., 2016. Kentsel Dönüşümde Mahalleler Arası Öncelik Sıralaması: Örnek Bir Karar Destek Sistemi. Uludağ University Journal of The Faculty of Engineering, 21(2), 377-402.

Altun, D., 2017. Konut Satın Alma Kararını Belirleyen Faktörler; Karaman İline Yönelik Bir Araștırma. Yayınlanmıș Yüksek Lisans Tezi. Karamanoğlu Mehmet Bey Üniversitesi, Karaman.

Aydın, G., ve Erdoğan, A., 2011. Web Tabanlı Bir Mekânsal Karar Destek Sistemi Tasarımı Ve Geliştirilmesi. Elektrik-Elektronik ve Bilgisayar Sempozyumu, Elazığ, Türkiye.

Baran, H., 2007. Ailelerin Konut Satın Alma Tutum ve Davranışları Üzerinde Bir Araştırma. Yayınlanmış Yüksek Lisans Tezi. Ankara Üniversitesi, Ankara.

Bostancı, B., Bakır, N. Y., Doğan, U., Güngör, M. K., 2017. Bulanık Karar Verme Teknikleri İle CBS Destekli Konut Memnuniyeti Araștırması. Gazi Üniversitesi Mühendislik-Mimarlık Fakültesi Dergisi, 32(4), 1193-1208.

Calabrese, A., Costa, R., Levialdi, N., Menichini, T., 2019. Integrating sustainability into strategic decision-making: A fuzzy AHP method for the selection of relevant sustainability issues. Technological Forecasting and Social Change, 139, 155-168.

Coşkun, Y., 2016. Konut Fiyatları Ve Yatııımı: Türkiye İçin Bir Analiz. Niğde Üniversitesi İktisadi ve İdari Bilimler Fakültesi Dergisi, 9(2), 201-217.

Çil, İ., Tokat, M. A., Türkan, Y. S., Doğan, N., 2014. Temel Eğitim Kurumlarında E-Rehberlik Ve Danıșmanlık Karar Destek Sistemi. Hacettepe Üniversitesi Eğitim Fakültesi Dergisi, 29(29-2), 34-56.

Daşkıran, F., 2015. Denizli Kentinde Konut Talebine Etki Eden Faktörlerin Hedonik Fiyatlandırma Modeli İle Tahmin Edilmesi. Journal of International Social Research, 8(37), 850-857.

Ecer, F., 2020. Multi-Criteria Decision Making For Green Supplier Selection Using İnterval Type-2 Fuzzy AHP: A Case Study Of A Home Appliance Manufacturer. Operational Research, 1-35.

Fei, L., Deng, Y., Hu, Y., 2019. DS-VIKOR: A New Multi-Criteria Decision-Making Method For Supplier Selection. International Journal of Fuzzy Systems, 21(1), 157-175.

Gayrimenkul ve Gayrimenkul Yatırım Ortaklığı Derneği (GYODER), 2013. 50 Soruda Tüketicinin Konut Alım Rehberi. https://www.gyoder.org.tr /uploads/Yayınlar/sektorel_yayinlar/GYODER_PDF_20131230164525_2506konut-al1mrehberi.pdf Erișim Tarihi: 10.01.2020.

Güneş, C., 2009. Türkiye'de Hanelerin Konut Tercihi: Ekonometrik Yaklaşım. Yayınlanmış Yüksek Lisans Tezi. Dokuz Eylül Üniversitesi, İzmir.

Hamurcu, M., Eren, T., 2015. Ankara Büyükșehir Belediyesi'nde CCok Ölçütlü Karar Verme Yöntemi ile Monoray Güzergâh Seçimi. 8. Uluslararası Ulaşım Teknolojileri Sempozyumu ve Fuarı, İstanbul, Türkiye.

Jahan, A., Zavadskas, E. K., 2019. ELECTRE-IDAT For Design Decision-Making Problems With Interval Data And Target-Based Criteria. Soft Computing, 23(1), 129-143.

Kamıșl Öztürk, Z., Güngör, K., Lepki, B., 2016. Lojistik Sektöründe Çok Amaçlı Kapı Atama Problemleri İçin Bir Karar Destek Sistemi. Mühendislik Bilimleri ve Tasarım Dergisi, 4(1), 21-29.

Kul, R. H., 2010. Uydu Kentlerin Tasarımı için Bir Karar Destek Sistemi ve Biliş̧im Sistemi Modeli Önerisi. Akademik Bilişim Kongresi, Muğla, Türkiye.

Liu, P., Cheng, S., Zhang, Y., 2019. An Extended Multi-Criteria Group Decision-Making Promethee Method Based On Probability Multi-Valued Neutrosophic Sets. International Journal of Fuzzy Systems, 21(2), 388-406.

Masud, A. S., Ravindran, A. R., 2008. Multiple Criteria Decision Making. CRC Press, An imprint of the Taylor and Francis Group.

Nuuter, T., Lill, I., 2014. From Public Rental to Home Ownership-Is it a Success Story?. 5th International Conference on Development, Energy, Environment, Economics, Florence, Italy.

Özgür, E. M., 2013. İkametgâh Memnuniyeti Bağlamında Konut Yeri Seçimi ve İkametgâh Hareketliliği: Bolu Kenti Örneği. Coğrafi Bilimler Dergisi, 11(2), 149-168.

Özkaraca, O., Acar, E., Peker, M., Türk, E., 2018. A Fuzzy Logic Based Clinical Decision Support System for Emergency Services. Mühendislik Bilimleri ve Tasarım Dergisi, 6(3), 375-382.

Power, D. J., 2002. Decision Support Systems: Concepts And Resources For Managers. Quorum Books Greenwood Publishing Group, 252s. London.

Rafi, S., Yu, W., Akbar, M. A., Alsanad, A., Gumaei, A., 2020. Multicriteria Based Decision Making of DevOps Data Quality Assessment Challenges Using Fuzzy TOPSIS. IEEE Access, 8, 46958-46980.

Sariçali, G., Kundakci, N., 2019. Bütünleşik Kemıra-M Ve Copras Yöntemi İle Mermer İşletmesi İçin Katrak Makinesi Seçimi 1. Kafkas University. Faculty of Economics and Administrative Sciences. Journal, 10(20), 1028-1061.

Şahin, Y, Supçiller, A., 2015. Tedarikçi Seçimi İçin Bir Karar Destek Sistemi. Mühendislik Bilimleri ve Tasarım Dergisi, 3(2), 91104.

Şengül, S., 2018. Düzce İl Merkezinde Ailelerin 1999 Depreminden Sonra Konut Satın Alma Davranış Biçimleri ve Bir Uygulama. Yayınlanmış Yüksek Lisans Tezi. Çankaya Üniversitesi, Ankara.

Şenyurt, Ö., Y., 2001. Konut Pazarlamasında Tüketicinin Satın Alma Davranışları ve Bir Uygulama. Yayınlanmıș Yüksek Lisans Tezi. Marmara Üniversitesi, İstanbul.

Tian, X., Xu, Z., Gu, J., 2019. Group Decision-Making Models For Venture Capitalists: The Promethee With Hesitant Fuzzy Linguistic İnformation. Technological and Economic Development of Economy, 25(5), 743-773. 
Tosun, E. K., Fırat, Z., 2012. Kentsel Mekandaki Değişimler ve Kişilerin Konut Tercihleri: Bursa Örneği. Business and Economics Research Journal, 3(1), 173-195.

Wikipedia, 2019. Weighted Sum Model https://en.wikipedia.org/wiki/Weighted_sum_model Erişim Tarihi: 11.05.2020.

Yavuz, S., Çemrek, F., 2013. Konjoint Analizi İle Sağlık Çalışanlarının Konut Tercihlerinin Belirlenmesi, Atatürk Üniversitesi Sosyal Bilimler Enstitüsü Dergisi, 17(2), 379-396.

Yayar, R., Deniz, G., 2014. Mersin Kent Merkezinde Konut Piyasası Fiyatlarının Hedonik Tahmini. Anadolu Üniversitesi Sosyal Bilimler Dergisi, 14(3), 87-100. 